\title{
Effect of Spacing and Weed Management Practices on Barnyard Millet (Echinochloa frumentaceae) under Rainfed Condition
}

\author{
C. Shamina ${ }^{1}$, K. Annadurai ${ }^{1 *}$, M. Hemalatha ${ }^{1}$ and S. Suresh ${ }^{2}$ \\ ${ }^{1}$ Department of Agronomy, AC \& RI, Killikulam, Tuticorin-6252824, India \\ ${ }^{2}$ Department of Soil Science and Agricultural Chemistry, AC \& RI, \\ Killikulam, Tuticorin-628252, India \\ *Corresponding author
}

\begin{tabular}{|l|}
\hline Ke y w o r d s \\
Spacing, Weed \\
management, Hand \\
weeding, \\
Pendimethalin, \\
Barnyard millet \\
\hline Article Info \\
\hline $\begin{array}{l}\text { Accepted: } \\
\text { 04 May } 2019 \\
\text { Available Online: } \\
\text { 10 June } 2019\end{array}$ \\
\hline
\end{tabular}

A B S T R A C T

Field experiment was carried out to assess suitable spacing and weed management practices under rainfed condition that can suppress weeds and enhance the growth of Barnyard millet (Echinochloa frumentaceae) during Rabi season of 2018 at Tamil Nadu Agricultural University, Killikulam, Tamil Nadu. Weed flora observed in experimental field consists of Echionocloacolonum under grasses, Cyperus rotundus under sedges and Amaranthus viridis, Boerhavia diffusa, Cleome viscosa, Commelina bengalensis, Phyllanthus niruri under Broad leaved weeds. Irrespective of weed management practices, total density, total dry weight of weeds and weed control efficiency were higher in weed free check $\left(T_{11}\right)$ which was on par with spacing of $25 \mathrm{~cm} \times 10 \mathrm{~cm}$ with hand weeding twice on 20 and 40 DAS $\left(\mathrm{T}_{2}\right) \mathrm{fb}$ spacing of $25 \mathrm{~cm} \mathrm{x} 10 \mathrm{~cm}$ with Pre emergence application of Pendimethalin@1 kg ai ha ${ }^{-1}+$ hand weeding on 20 DAS $\left(\mathrm{T}_{4}\right)$ and spacing of $30 \mathrm{~cm} \times 10$ $\mathrm{cm}$ with hand weeding twice on 20 and 40 DAS $\left(\mathrm{T}_{5}\right)$ over unweeded control $\left(\mathrm{T}_{12}\right)$. Grain and straw yield (1681 and $3975 \mathrm{~kg} / \mathrm{ha}$, respectively) were significantly higher with weed free check $\left(\mathrm{T}_{11}\right)$ as compared to Unweeded control $\left(\mathrm{T}_{12}\right)$. The net return and B: C ratio (Rs. 26502 per ha and 2.17, respectively) were significantly higher with weed free check $\left(\mathrm{T}_{11}\right)$ which was on par with spacing of $25 \mathrm{~cm}$ x $10 \mathrm{~cm}$ with hand weeding twice on 20 and 40 DAS $\left(\mathrm{T}_{2}\right) \mathrm{fb}$ spacing of $25 \mathrm{~cm}$ x $10 \mathrm{~cm}$ with Pre emergence application of Pendimethalin @ $1 \mathrm{~kg}$ ai ha ${ }^{-1}+$ hand weeding on 20 DAS $\left(\mathrm{T}_{4}\right)$ and spacing of $30 \mathrm{~cm}$ x $10 \mathrm{~cm}$ with hand weeding twice on 20 and $40 \mathrm{DAS}\left(\mathrm{T}_{5}\right)$. Unweeded control $\left(\mathrm{T}_{12}\right)$ recorded significantly minimum net returns (Rs.6933 per ha) and benefit: cost ratio (Rs.1.34). The result shows that both spacing and weed management practices had the ability of suppressing weeds. Hand weeding twice and narrow spacing had strong and negative effects on weed biomass and positive effects on crop biomass and yield.

\section{Introduction}

Barnyard millet (Echinochloa frumentaceae) is cultivated and grown as cereal with nativity of Eurasia. It is important minor millet belonging to the family Poaceae. It is a grain crop of lesser importance. It is drought tolerant crop capable of withstanding waterlogged conditions. It is a fastest multipurpose crop, which yields food and forage in 
a short duration and at low inputs even under adverse climatic conditions. In India, Japan and China, Barnyard millet was often used as a substitute for rice when the paddy crop fails. In the U.S.A. it is grown primarily for forage, and can produce up to eight harvests a year. It does not require more irrigation. Barnyard Millet is considered the least important of cereals, with annual production less than $2 \%$ of the world's grain. It is found in most of the southern and central states in India especially wherever annual rainfall is below $350 \mathrm{~mm}$, whereas no other cereal crop can grow under such moisture stress.

Nutritionally, Barnyard millet is an important crop. It is a rich source of protein (11.8\%) and crude fibre $(9.8 \%)$. Out of the total protein; it also consists of $16.6 \%$ of amino acid leucine, which is twice the quantity of Rice, which is highly digestible and is an excellent source of dietary fibre with good amounts of soluble and insoluble fractions. The grains of barnyard millet are low in phytic acid and rich in iron and calcium contents (Sampath et al., 1990). The carbohydrate content is low and slowly digestible, which makes the Barnyard millet a natural designer food. In the present days of increased diabetes mellitus, Barnyard millet could become an ideal food.

In the year of 2014-2015, the total production of minor millets in India is 6.83 lakh tonnes, cultivated in area about 6 lakh hectares with an average productivity of $630 \mathrm{~kg} \mathrm{ha}^{-1}$. In Tamil Nadu small millets are cultivated in an area of 32000 ha with a production of about $35000 \mathrm{t}$. The average productivity of small millets is about $1086 \mathrm{~kg} \mathrm{ha}^{-1}$ (Agricultural statistics at a Glance, 2015). Appropriate inter-row spacing will help the crop to compete with weed. Several reports indicated that crops planted in narrow row spacing suppress weed growth more than in wide row spacing because high density of crop in narrower inter row spacing resulting in lower weeds infestation which was suppressed by crops. It is a need of determining suitable inter-row spacing for suppression of weeds with effective weed management practices either by herbicide application or manual or mechanical weeding to increase the crop yield, crop quality and reduce production cost.

\section{Materials and Methods}

Field experiment was carried out during Rabi season of 2018 at Tamil Nadu Agricultural University, Killikulam, Tamil Nadu. The soil of the experimental field was sandy clay loam soil in texture with low in available organic carbon $(5.6 \mathrm{~g} / \mathrm{kg}$ soil) and available nitrogen $(230 \mathrm{~kg} / \mathrm{ha})$ but medium in available phosphorus (22 kg/ha) and potassium (256 $\mathrm{kg} / \mathrm{ha}$ ) with a $\mathrm{pH}$ of 7.8 . The experiment consisting of 12 treatments and were factorially arranged and laid out in a Randomized Complete Block Design with three replications. The experiment was conducted in randomized block design replicated thrice with twelve different weed management practices viz., broadcasting (seeds of $10 \mathrm{~kg} \mathrm{ha}^{-1}$ ) + Hand weeding twice on 20 and 40 DAS $\left(\mathrm{T}_{1}\right)$, spacing of $25 \mathrm{~cm} \times$ $10 \mathrm{~cm}+$ Hand weeding twice on 20 and 40 DAS $\left(\mathrm{T}_{2}\right)$, spacing of $25 \mathrm{~cm} \times 10 \mathrm{~cm}+$ one Hand weeding twice on $20+$ one Mechanical weeding on 40 DAS $\left(\mathrm{T}_{3}\right)$, spacing of $25 \mathrm{~cm} \mathrm{x}$ $10 \mathrm{~cm}+$ PE Pendimethalin@ $1 \mathrm{~kg}$ ai ha ${ }^{-1}$ followed by Hand weeding on 40 DAS $\left(\mathrm{T}_{4}\right)$, spacing of $30 \mathrm{~cm} \times 10 \mathrm{~cm}+$ hand weeding twice on 20 and 40 DAS $\left(T_{5}\right)$, spacing of 30 $\mathrm{cm} \times 10 \mathrm{~cm}+$ one hand weeding twice on 20 + one Mechanical weeding on 40 DAS $\left(\mathrm{T}_{6}\right)$, spacing of $30 \mathrm{~cm} \times 10 \mathrm{~cm}+\mathrm{PE}$ Pendimethalin@ @ $\mathrm{kg}$ ai ha ${ }^{-1}$ followed by hand weeding on 40 DAS $\left(\mathrm{T}_{7}\right)$, spacing of 40 $\mathrm{cm} \times 10 \mathrm{~cm}+$ hand weeding twice on 20 and 40 DAS $\left(\mathrm{T}_{8}\right)$, spacing of $40 \mathrm{~cm} \times 10 \mathrm{~cm}+$ one hand weeding twice on $20 \mathrm{DAS}+$ one Mechanical weeding on $40 \mathrm{DAS}\left(\mathrm{T}_{9}\right)$, spacing 
of $40 \mathrm{~cm} \times 10 \mathrm{~cm}+$ PE Pendimethalin @ 1kg ai ha ${ }^{-1}$ followed by hand weeding on 40 DAS $\left(\mathrm{T}_{10}\right)$,Weed-free $\quad \operatorname{check}\left(\mathrm{T}_{11}\right), \quad$ Unweeded control $\left(\mathrm{T}_{12}\right)$.

The variety used for the experiment was MDU 1. A recommended dose of fertilizers (40:20:0 N: $\mathrm{P}_{2} \mathrm{O}_{5}: \mathrm{K}_{2} \mathrm{O} \mathrm{kg} / \mathrm{ha}$ ) was applied equally to each plot. Nitrogen was applied in two splits. Half dose of $\mathrm{N}(20 \mathrm{~kg} / \mathrm{ha})$ along with full dose of $\mathrm{P}_{2} \mathrm{O}_{5}(20 \mathrm{~kg} / \mathrm{ha})$ were applied as basal and remaining $\mathrm{N}(20 \mathrm{~kg} / \mathrm{ha})$ was applied as top dressing after 30 days of sowing. The source for nitrogen and phosphorous were urea, di-ammonium phosphate respectively. Weed counts (No. $\left.\mathrm{m}^{-2}\right)$ and dry weight $\left(\mathrm{g} \mathrm{m}^{-2}\right)$ were recorded by putting a quadrate $(25 \mathrm{~cm} \times 25 \mathrm{~cm})$ at two random spots in each plot at 45 DAS of the crop. Weed control efficiency (WCE) was also calculated on the basis of dry matter production of weeds. The experimental data recorded for growth, yield attributes and yield were statistically analysed. Data on weed density and dry weight of weeds were transformed using square root transformation $(\sqrt{X}+0.5)$ before statistical analysis.

\section{Results and Discussion}

\section{Effect on weeds}

Weed flora observed in experimental field were classified as Grasses, Sedges and Broad leaved weeds. There were seven species belonging to seven families. Weed flora consists of Echionocloa colonum under grasses, Cyperus rotundus under sedges and Amaranthus viridis, Boerhavia diffusa, Cleome viscosa, Commelina bengalensis, Phyllanthus niruri under Broad leaved weeds as reported by Gowda et al., (2012).

Weed free check $\left(\mathrm{T}_{11}\right)$ significantly reduced the density of grasses, sedge and broad leaved weeds $\left(0.43\right.$ No.m ${ }^{-2}, 1.0$ No.m ${ }^{-2}$ and 1.1 No. $\mathrm{m}^{-2}$, respectively) at 45 DAS which was on par with spacing of $25 \mathrm{~cm} \times 10 \mathrm{~cm}$ with hand weeding twice on 20 and 40 DAS $\left(\mathrm{T}_{2}\right) f b$ spacing of $25 \mathrm{~cm} \times 10 \mathrm{~cm}$ with Pre emergence application of Pendimethalin @ $1 \mathrm{~kg}$ ai ha ${ }^{-1}+$ hand weeding on $20 \mathrm{DAS}\left(\mathrm{T}_{4}\right)$ and spacing of $30 \mathrm{~cm} \times 10 \mathrm{~cm}+$ hand weeding twice on 20 and 40 DAS $\left(T_{5}\right)$. Among weed management practices, weed free check $\left(T_{11}\right)$ had significantly reduced dry weight of grasses, sedges and broad leaved weeds $\left(0.20 \mathrm{~g} \mathrm{~m}^{-2}\right.$, $0.34 \mathrm{~g} \mathrm{~m}^{-2}$ and $0.59 \mathrm{~g} \mathrm{~m}^{-2}$, respectively) at 45 days after sowing which was on par with spacing of $25 \mathrm{~cm} \times 10 \mathrm{~cm}$ with hand weeding twice on 20 and 40 DAS $\left(\mathrm{T}_{2}\right) f b$ spacing of 25 $\mathrm{cm} \times 10 \mathrm{~cm}$ with Pre emergence application of Pendimethalin @1 kg ai ha ${ }^{-1}+$ hand weeding on 20 DAS $\left(\mathrm{T}_{4}\right)$ as compared to other treatments. Whereas, unweeded control $\left(\mathrm{T}_{11}\right)$ recorded significantly higher weed population and weed dry weight, respectively. The reduction in the weed population and weed dry weight in these treatments was mainly due to effective control of weeds at all stages of crop growth period. These results are in conformity with the findings of Sanjoy Saha (2005) and Madhu Kumar et al., (2013). However, the weed control efficiency $(98.18 \%)$ was also highest with weed free check $\left(T_{11}\right)$ given in Table 1 . This was mainly due to better control of weeds right from sowing to45 DAS, which is the critical period for crop weed competition. These results are in conformity with the findings of Pradhan et al., (2010).

\section{Effect on growth and yield attributes of crop}

All weed management practices significantly improved the growth and yield attributes of Barnyard millet over unweeded control (Table 2). Plant spacing plays an important role on growth, development and yield of crops. In general, yield of millets is greatly affected by the plant population and higher yield could be 
achieved with increasing plant population to a greater extent. Barker (1996) reported that when millet is grown in narrow spacing, lower weed pressure and weed composition was observed as compared to wider spacing.

Table.1 Effect of spacing and weed management practices on weed density, weed dry weight and weed control efficiency at 45 DAS in barnyard millet under rainfed condition

\begin{tabular}{|c|c|c|c|c|c|c|c|}
\hline \multirow[t]{2}{*}{ Treatments } & \multicolumn{3}{|c|}{$\begin{array}{l}\text { Weed density } \\
\left(\text { No.m }^{-2}\right)\end{array}$} & \multicolumn{3}{|c|}{$\begin{array}{l}\text { Weed dry matter production } \\
\qquad\left(\mathrm{g} \mathrm{m}^{-2}\right)\end{array}$} & \multirow[t]{2}{*}{ WCE(\%) } \\
\hline & Grasses & Sedges & $\begin{array}{l}\text { Broad } \\
\text { leaved } \\
\text { weeds }\end{array}$ & Grasses & Sedges & $\begin{array}{l}\text { Broad } \\
\text { leaved } \\
\text { weeds }\end{array}$ & \\
\hline $\begin{array}{l}\mathrm{T}_{1:} \text { Broadcasting } 10 \mathrm{~kg} \text { seeds } \\
\text { /ha+ } 2 \mathrm{HW} \text { on } 20 \text { and } 40 \mathrm{DAS}\end{array}$ & $4.39(2.21)$ & $\begin{array}{c}6.33 \\
(2.72)\end{array}$ & $4.4(2.21)$ & 1.21 & 2.13 & 2.35 & 89.43 \\
\hline $\begin{array}{l}T_{2:} \text { Spacing of } 25 \mathrm{~cm} \times 10 \mathrm{~cm}+2 \\
\text { HW on } 20 \text { and } 40 \text { DAS }\end{array}$ & $1.27(1.33)$ & $\begin{array}{c}2.13 \\
(1.62)\end{array}$ & $2.1(1.63)$ & 0.43 & 0.70 & 1.42 & 96.08 \\
\hline $\begin{array}{l}T_{3} \text { : Spacing of } 25 \mathrm{~cm} \times 10 \mathrm{~cm} \\
+1 \text { HW on 20 DAS }+1 \\
\text { Mechanical Weeding on } 40 \\
\text { DAS }\end{array}$ & $3.51(2.00)$ & $\begin{array}{l}5.97 \\
(2.54)\end{array}$ & $4.4(2.23)$ & 1.36 & 2.01 & 2.37 & 90.20 \\
\hline $\begin{array}{l}\text { T: }_{4 \text { : }} \text { Spacing of } 25 \mathrm{~cm} \times 10 \mathrm{~cm}+ \\
\text { PE Pendimethalin } 1 \mathrm{Kg} \text { ai ha } \\
\text { fb } 1 \mathrm{HW} \text { on } 20 \mathrm{DAS}\end{array}$ & $2.97(1.87)$ & $\begin{array}{l}5.53 \\
(2.46)\end{array}$ & $3.2(1.92)$ & 1.16 & 1.76 & 1.75 & 91.74 \\
\hline $\begin{array}{l}T_{5} \text { : Spacing of } 30 \mathrm{~cm} \times 10 \mathrm{~cm}+2 \\
\text { HW on } 20 \text { and } 40 \text { DAS }\end{array}$ & $3.10(1.90)$ & $\begin{array}{c}5.40 \\
(2.43)\end{array}$ & $3.2(1.92)$ & 1.19 & 1.75 & 1.76 & 91.88 \\
\hline $\begin{array}{l}T_{6:} \text { Spacing of } 30 \mathrm{~cm} \times 10 \mathrm{~cm}+1 \\
\text { HW on } 20 \text { DAS }+1 \text { Mechanical } \\
\text { Weeding on } 40 \text { DAS }\end{array}$ & $3.88(2.09)$ & $\begin{array}{l}6.80 \\
(2.70)\end{array}$ & $3.7(2.06)$ & 1.68 & 2.24 & 2.06 & 89.85 \\
\hline $\begin{array}{l}\text { T}_{7} \text { : Spacing of } 30 \mathrm{~cm} \times 10 \mathrm{~cm}+ \\
\text { PE Pendimethalin } 1 \mathrm{Kg} \text { ai } \mathrm{ha}^{-1} \\
\text { fb } 1 \mathrm{HW} \text { on } 20 \mathrm{DAS}\end{array}$ & $\begin{array}{l}4.30 \\
(2.19)\end{array}$ & $\begin{array}{c}6.77 \\
(2.70)\end{array}$ & $\begin{array}{c}4.5 \\
(2.24)\end{array}$ & 1.65 & 2.29 & 2.43 & 89.08 \\
\hline $\begin{array}{l}T_{8:} \text { Spacing of } 40 \mathrm{~cm} \times 10 \mathrm{~cm}+2 \\
\text { HW on } 20 \text { and } 40 \text { DAS }\end{array}$ & $\begin{array}{c}4.42 \\
(2.22)\end{array}$ & $\begin{array}{c}7.93 \\
(2.90)\end{array}$ & $\begin{array}{c}3.8 \\
(2.08)\end{array}$ & 1.85 & 2.57 & 2.18 & 88.66 \\
\hline $\begin{array}{l}T_{9:} \text { Spacing of } 40 \mathrm{~cm} \times 10 \mathrm{~cm}+1 \\
\text { HW on } 20 \text { DAS }+1 \text { Mechanical } \\
\text { Weeding on } 40 \text { DAS }\end{array}$ & $5.11(2.37)$ & $\begin{array}{c}6.97 \\
(2.73)\end{array}$ & $3.3(1.96)$ & 2.13 & 2.93 & 1.79 & 89.15 \\
\hline $\begin{array}{l}\text { T}_{10} \text { Spacing of } 40 \mathrm{~cm} \times 10 \mathrm{~cm}+ \\
\text { PE Pendimethalin } 1 \mathrm{Kg} \text { ai ha }{ }^{-1} \\
\text { fb } 1 \mathrm{HW} \text { on } 20 \mathrm{DAS}\end{array}$ & $4.03(2.13)$ & $\begin{array}{c}7.27 \\
(2.79)\end{array}$ & $4.6(2.25)$ & 1.57 & 2.78 & 2.42 & 88.87 \\
\hline $\mathbf{T}_{11:}$ Weed free check & $0.43(0.97)$ & $\begin{array}{c}1.00 \\
(1.22) \\
\end{array}$ & $1.1(1.28)$ & 0.20 & 0.34 & 0.59 & 98.18 \\
\hline $\mathbf{T}_{12:}$ Unweeded control & $\begin{array}{l}34.91 \\
(5.95)\end{array}$ & $\begin{array}{l}71.60 \\
(8.48)\end{array}$ & $\begin{array}{c}36.4 \\
(6.07)\end{array}$ & 13.92 & 23.2 & 20.9 & 0.00 \\
\hline SEd & 0.03 & 0.09 & 0.09 & 0.25 & 0.24 & 0.21 & \\
\hline $\mathrm{CD}(\mathrm{P}=0.05)$ & 0.07 & 0.19 & 0.19 & 0.53 & 0.50 & 0.44 & \\
\hline
\end{tabular}

Actual figures are transformed to $\sqrt{ } \mathbf{X + 0 . 5}$ and population figures are given in Parenthesis. 
Table.2 Effect of spacing and weed management practices on growth and yield attributes of barnyard millet under rainfed condition

\begin{tabular}{|c|c|c|c|c|}
\hline Treatments & $\begin{array}{c}\text { Plant height } \\
\text { (cm) at harvest }\end{array}$ & LAI at 60 DAS & $\begin{array}{l}\text { Number of } \\
\text { productive } \\
\text { tillers }\left(\mathbf{m}^{-2}\right)\end{array}$ & $\begin{array}{l}\text { Length of } \\
\text { panicle }(\mathrm{cm})\end{array}$ \\
\hline $\begin{array}{l}T_{1:} \text { Broadcasting } 10 \mathrm{~kg} \text { seeds } / \mathrm{ha}+2 \mathrm{HW} \\
\text { on } 20 \text { and } 40 \text { DAS }\end{array}$ & 111.28 & 4.56 & 103.5 & 12.2 \\
\hline $\begin{array}{l}T_{2:} \text { Spacing of } 25 \mathrm{~cm} \times 10 \mathrm{~cm}+2 \mathrm{HW} \text { on } \\
20 \text { and } 40 \text { DAS }\end{array}$ & 129.12 & 8.42 & 176 & 14.5 \\
\hline $\begin{array}{l}T_{3:} \text { Spacing of } 25 \mathrm{~cm} \times 10 \mathrm{~cm}+1 \mathrm{HW} \text { on } \\
20 \text { DAS }+1 \text { Mechanical Weeding on } 40 \\
\text { DAS }\end{array}$ & 106.34 & 6.57 & 132 & 13.8 \\
\hline $\begin{array}{l}\text { T }_{4} \text { Spacing of } 25 \mathrm{~cm} \times 10 \mathrm{~cm}+\mathrm{PE} \\
\text { Pendimethalin } 1 \mathrm{~kg} \mathrm{ai} \mathrm{ha}^{-1} \mathrm{fb} 1 \mathrm{HW} \text { on } 20 \\
\text { DAS }\end{array}$ & 122.00 & 7.09 & 163 & 14.0 \\
\hline $\begin{array}{l}T_{5} \text { : Spacing of } 30 \mathrm{~cm} \times 10 \mathrm{~cm}+2 \mathrm{HW} \text { on } \\
20 \text { and } 40 \text { DAS }\end{array}$ & 121.47 & 7.02 & 131 & 13.7 \\
\hline $\begin{array}{l}T_{6:} \text { Spacing of } 30 \mathrm{~cm} \times 10 \mathrm{~cm}+1 \mathrm{HW} \text { on } \\
20 \text { DAS }+1 \text { Mechanical Weeding on } 40 \\
\text { DAS }\end{array}$ & 110.68 & 6.43 & 124 & 13.6 \\
\hline $\begin{array}{l}T_{7} \text { : Spacing of } 30 \mathrm{~cm} \times 10 \mathrm{~cm}+\mathrm{PE} \\
\text { Pendimethalin } 1 \mathrm{Kg}^{\text {ai ha }}{ }^{-1} \mathrm{fb} 1 \mathrm{HW} \text { on } 20 \\
\text { DAS }\end{array}$ & 112.75 & 6.28 & 134 & 13.3 \\
\hline $\begin{array}{l}T_{8:} \text { Spacing of } 40 \mathrm{~cm} \times 10 \mathrm{~cm}+2 \mathrm{HW} \text { on } \\
20 \text { and } 40 \text { DAS }\end{array}$ & 106.25 & 5.21 & 104 & 13.1 \\
\hline $\begin{array}{l}\text { T: }_{9} \text { Spacing of } 40 \mathrm{~cm} \times 10 \mathrm{~cm}+1 \mathrm{HW} \text { on } \\
20 \text { DAS + } 1 \text { Mechanical Weeding on } 40 \\
\text { DAS }\end{array}$ & 107.32 & 5.98 & 110 & 12.7 \\
\hline $\begin{array}{l}\text { T }_{10} \text { Spacing of } 40 \mathrm{~cm} \times 10 \mathrm{~cm}+\mathrm{PE} \\
\text { Pendimethalin } 1 \mathrm{Kg}^{\text {ai ha }}{ }^{-1} \mathrm{fb} 1 \mathrm{HW} \text { on } 20 \\
\text { DAS }\end{array}$ & 104.68 & 5.13 & 105 & 12.6 \\
\hline$T_{11:}$ Weed free check & 129.69 & 8.53 & 176 & 14.6 \\
\hline $\mathbf{T}_{12:}$ Unweeded control & 96.73 & 3.52 & 97 & 11.8 \\
\hline SEd & 0.76 & 0.16 & 5.32 & 0.08 \\
\hline $\mathrm{CD}(\mathrm{P}=\mathbf{0 . 0 5})$ & 1.59 & 0.36 & 11.04 & 0.17 \\
\hline
\end{tabular}


Table.3 Effect of spacing and weed management practices on yield and economics of barnyard millet under rainfed condition

\begin{tabular}{|c|c|c|c|c|c|c|}
\hline Treatments & $\begin{array}{c}\text { Grain } \\
\text { yield(kg } \\
\left.\text { ha }^{-1}\right)\end{array}$ & $\begin{array}{c}\text { Stover } \\
\text { yield }(k g \\
\left.\text { ha }^{-1}\right)\end{array}$ & $\begin{array}{c}\text { Cost of } \\
\text { cultivation } \\
\left(\square . \text { ha }^{-1}\right)\end{array}$ & $\begin{array}{l}\text { Gross } \\
\text { return } \\
\left(\square . \text { ha }^{-1}\right)\end{array}$ & $\begin{array}{c}\text { Net } \\
\text { return } \\
\left(\square . \text { ha }^{-1}\right)\end{array}$ & $\begin{array}{l}\text { B:C } \\
\text { ratio }\end{array}$ \\
\hline $\begin{array}{l}T_{1:} \text { Broadcasting } 10 \mathrm{~kg} \text { seeds } / \mathrm{ha}+2 \\
\text { HW on } 20 \text { and } 40 \text { DAS }\end{array}$ & 1075 & 3049 & 22563 & 36579 & 14016 & 1.62 \\
\hline $\begin{array}{l}T_{2:} \text { Spacing of } 25 \mathrm{~cm} \times 10 \mathrm{~cm}+2 \\
H W \text { on } 20 \text { and } 40 \text { DAS }\end{array}$ & 1678 & 3944 & 22563 & 48834 & 26271 & 2.16 \\
\hline $\begin{array}{l}T_{3:} \text { Spacing of } 25 \mathrm{~cm} \times 10 \mathrm{~cm}+1 \mathrm{HW} \\
\text { on } 20 \text { DAS + } 1 \text { Mechanical Weeding } \\
\text { on } 40 \text { DAS }\end{array}$ & 1096 & 3412 & 22658 & 36912 & 14254 & 1.63 \\
\hline $\begin{array}{l}\mathrm{T}_{4} \text { : Spacing of } 25 \mathrm{~cm} \times 10 \mathrm{~cm}+\mathrm{PE} \\
\text { Pendimethalin } 1 \mathrm{Kg} \text { ai ha }{ }^{-1} \mathrm{fb} 1 \mathrm{HW} \\
\text { on } 20 \text { DAS }\end{array}$ & 1290 & 3594 & 22627 & 40914 & 18287 & 1.81 \\
\hline $\begin{array}{l}T_{5} \text { : Spacing of } 30 \mathrm{~cm} \times 10 \mathrm{~cm}+2 \\
\text { HW on } 20 \text { and } 40 \text { DAS }\end{array}$ & 1289 & 3592 & 22563 & 40887 & 18324 & 1.81 \\
\hline $\begin{array}{l}T_{6:} \text { Spacing of } 30 \mathrm{~cm} \times 10 \mathrm{~cm}+1 \mathrm{HW} \\
\text { on } 20 \text { DAS + } 1 \text { Mechanical Weeding } \\
\text { on } 40 \text { DAS }\end{array}$ & 1109 & 3443 & 22658 & 37293 & 14635 & 1.65 \\
\hline $\begin{array}{l}\mathrm{T}_{7} \text { : Spacing of } 30 \mathrm{~cm} \times 10 \mathrm{~cm}+\mathrm{PE} \\
\text { Pendimethalin } 1 \mathrm{Kg}^{\mathrm{ai}} \mathrm{ha}^{-1} \mathrm{fb} 1 \mathrm{HW} \\
\text { on } 20 \text { DAS }\end{array}$ & 1179 & 3419 & 22627 & 38199 & 15572 & 1.69 \\
\hline $\begin{array}{l}T_{8:} \text { Spacing of } 40 \mathrm{~cm} \times 10 \mathrm{~cm}+2 \mathrm{HW} \\
\text { on } 20 \text { and } 40 \text { DAS }\end{array}$ & 1006 & 3337 & 22563 & 35112 & 12549 & 1.56 \\
\hline $\begin{array}{l}\text { T: Spacing of } 40 \mathrm{~cm} \times 10 \mathrm{~cm}+1 \mathrm{HW} \\
\text { on } 20 \text { DAS + } 1 \text { Mechanical Weeding } \\
\text { on } 40 \text { DAS }\end{array}$ & 986 & 3095 & 22658 & 33405 & 10747 & 1.47 \\
\hline $\begin{array}{l}T_{10:} \text { Spacing of } 40 \mathrm{~cm} \times 10 \mathrm{~cm}+\mathrm{PE} \\
\text { Pendimethalin } 1 \mathrm{Kg} \text { ai ha }{ }^{-1} \mathrm{fb} 1 \mathrm{HW} \\
\text { on } 20 \text { DAS }\end{array}$ & 1010 & 3273 & 22627 & 34788 & 12161 & 1.54 \\
\hline$T_{11:}$ Weed free check & 1681 & 3975 & 22563 & 49065 & 26502 & 2.17 \\
\hline $\mathbf{T}_{12:}$ Unweeded control & 837 & 2449 & 20316 & 27249 & 6933 & 1.34 \\
\hline SEd & 48.24 & 57.71 & NA & NA & NA & NA \\
\hline $\mathrm{CD}(\mathrm{P}=0.05)$ & 100.04 & 119.70 & - & - & - & - \\
\hline
\end{tabular}

The highest values of plant height $(129.69 \mathrm{~cm}$ at 90 DAS), leaf area index (5.69 at $60 \mathrm{DAS})$, number of productive tillers $\left(176 \mathrm{~m}^{-2}\right.$ at maturity), length of panicle $(14.6 \mathrm{~cm}$ at maturity) were recorded under weed free check $\left(\mathrm{T}_{11}\right)$ which was on par with spacing of $25 \mathrm{~cm} \times 10 \mathrm{~cm}$ with hand weeding twice on 20 and 40 DAS $\left(\mathrm{T}_{2}\right) f b$ spacing of $25 \mathrm{~cm} \times 10$ $\mathrm{cm}$ with Pre emergence application of Pendimethalin@1 kg ai ha ${ }^{-1}+$ hand weeding on 20 DAS $\left(\mathrm{T}_{4}\right)$ and spacing of $30 \mathrm{~cm} \times 10$ $\mathrm{cm}+$ hand weeding twice on 20 and 40 DAS $\left(T_{5}\right)$. The enhancement of crop growth and yield attributes components could be due to less competition by the weeds for crop these factors throughout the crop growth period due 
to control of early emerged weeds before sowing through pre-emergence application of herbicides and late emerged weeds through manual weeding. Similar results were reported by Prashanth Kumar et al., (2015) and Prithvi et al., (2015).

\section{Effect on yield of crop}

Data pertaining to Yield of Barnyard millet, in which weed free check $\left(T_{11}\right)$ recorded significantly higher grain and stover yield (1681 kg/ha and $3975 \mathrm{~kg} / \mathrm{ha}$, respectively) among different weed management practices which was on par with spacing of $25 \mathrm{~cm} \times 10$ $\mathrm{cm}$ with hand weeding twice on 20 and 40 DAS $\left(\mathrm{T}_{2}\right)$ as compared to unweeded control $\left(\mathrm{T}_{12}\right)$ (Table 3). The minimum grain and straw yield in unweeded control could be due to the severe weed competition as evidenced by the maximum weed density, weed dry matter which resulted in less number of tillers, lower plant dry matter and plant height. Reduction in grain yield of Barnyard millet was due to weed competition was reported by Prashanth Kumar et al., (2015) and Prithvi et al., (2015).

\section{Effect on economics}

A critical analysis of data on economics revealed that the highest gross returns (Rs.49065 $\mathrm{ha}^{-1}$ ) was obtained with weed free $\operatorname{check}\left(\mathrm{T}_{11}\right)$. But higher cost of cultivation in weed free check (Hand weeding twice) due to engagement of more labourers for weeding. This confirms the finding of Tuti et al., (2016).Spacing of $25 \mathrm{~cm} \times 10 \mathrm{~cm}$ with Pre emergence application of Pendimethalin @1 $\mathrm{kg}$ ai ha $\mathrm{ha}^{-1}+$ hand weeding on $20 \operatorname{DAS}\left(\mathrm{T}_{4}\right)$ compared to weed free $\operatorname{check}\left(\mathrm{T}_{11}\right)$. Maximum net return (Rs.26502ha ${ }^{-1}$ ) and benefit: cost ratio (2.17) were obtained with weed free check $\left(\mathrm{T}_{11}\right)$ which was on par with spacing of $25 \mathrm{~cm} \times 10 \mathrm{~cm}$ with hand weeding twice on 20 and 40 DAS $\left(\mathrm{T}_{2}\right) f b$ spacing of $25 \mathrm{~cm} \mathrm{x} 10$ $\mathrm{cm}$ with Pre emergence application of
Pendimethalin @1 kg ai ha ${ }^{-1}+$ hand weeding on 20 DAS( $\left.\mathrm{T}_{4}\right)$ (Table 3). This confirms the finding of Khaliq et al., (2011). On the basis of result obtained, it can be concluded that hand weeding twice with narrow spacing of $25 \mathrm{~cm} \times 10 \mathrm{~cm}\left(\mathrm{~T}_{2}\right)$ found to be best as weed management practice for better weed control efficiency, crop growth, higher productivity and profitability in line sown rainfed barnyard millet.

\section{References}

Agricultural Statistics at a Glance. 2015. Directorate of Economics and Statistics. Ministry of Agriculture, Govt. of India, pp 73-74.

Barker, R.D., 1996. Millet production Guide. A. 414.

Gowda, S.G.K., Naveen, D.V., Bhagyalakshmi, T. and Gowda, R.C. 2012. Weed management practices on nutrient removal by weeds and its relation to yield of finger millet in eastern dry zone of Karnataka. International Journal of Agricultural Sciences. 8 (2):385-389

Khaliq, A., Riaz, M. Y. and Matloob, A., 2011. Bio-economic assessment of chemical and non-chemical weed management strategies in dry seeded fine rice (Oryza sativa L.) Journal of Plant Breeding and Crop Science. 3(12): 302-310.

Madhu Kumar, V., Kalyana Murthy, K. N., Sanjay, M. T., Prashanth, R. and Sunil, C. M. 2013. Growth and yield attributes of aerobic rice as influenced by application of pre and post emergent herbicides. Plant Archives. 13(2): 771-774.

Pradhan, A., Rajput, A.S., and Thakur, A. 2010. Effect of weed management on growth and yield of finger millet. Indian Journal of Weed Science. 42(1\&2): 53-56. 
Prashanth Kumar, M.K., Shekara, B.G., Yamuna, B.G. and Sunil, C.M. 2015. Crop Weed Competition for Nutrients by Weed and Drill Sown Finger millet (Eleusinec oracana L. Gaertn.). National Academy of Agriculture Science. 33(3): 2049- 2054.

Prithvi, K.B., Rao, A.S. and Srinivasulu, K. 2015. Weed management in transplanted ragi. Indian Journal of Weed Science. 47(2): 214-215.
Sanjoy Saha. 2005. Evaluation of some new herbicide formulations alone or in combination with hand weeding in direct sown rainfed low land rice. Indian Journal of Weed Science. 37(1\&2): 103-104.

Tuti, M.D., Singh, S., Pandey, B.M., Bisht, J.K. and Pattanayak, A. 2016. Weed management in rainfed finger millet. Indian Journal of Weed Science. 48(1): 74-75.

\section{How to cite this article:}

Shamina, C., K. Annadurai, M. Hemalatha and Suresh, S. 2019. Effect of Spacing and Weed Management Practices on Barnyard Millet (Echinochloa frumentaceae) under Rainfed Condition. Int.J.Curr.Microbiol.App.Sci. 8(06): 330-337. doi: https://doi.org/10.20546/ijcmas.2019.806.037 